\title{
Improvement of single-cell gel electrophoresis (SCGE) alkaline comet assay
}

\author{
Xiang-Rong $\mathrm{Xu}^{1}$, Jun-Quan $\mathrm{Zhu}^{2}$, Ting $\mathrm{Ye}^{2}$, Chun-Lin Wang ${ }^{2}$, Yi-Feng $\mathrm{Zhu}^{2}$, \\ Hans-Uwe Dahms ${ }^{3, * *}$, Fan Jin ${ }^{1, * *}$, Wan-Xi Yang ${ }^{4, *}$ \\ ${ }^{1}$ Department of Reproductive Endocrinology, Key Laboratory of Reproductive Genetics, Women's Hospital, \\ Zhejiang University School of Medicine, 1 Xueshi Road, Hangzhou 310006, China \\ ${ }^{2}$ Key Laboratory of Applied Marine Biotechnology by the Ministry of Education, Ningbo University, Ningbo 315211, China \\ ${ }^{3}$ Green Life Science Department, College of Natural Science, Sangmyung University, 7 Hongji-dong, Jongno-gu, \\ Seoul 110-743, South Korea \\ ${ }^{4}$ The Sperm Laboratory, College of Life Sciences, Zhejiang University, Hangzhou 310058, China
}

\begin{abstract}
Although the single-cell gel electrophoresis (SCGE) alkaline comet assay can detect DNA damage quickly and with high sensitivity, it does not work well for cryopreserved sperm of some marine teleosts. Using large yellow croaker Pseudosciaena crocea sperm that were cryopreserved in increasing concentrations (5 to $30 \%$ ) of DMSO, we made modifications to the classic SCGE method that included using common microscopic slides without rough surfaces, pretreatment of sperm before gel spread, and a single layer of gel. Electrophoresis conditions were $130 \mathrm{~mA}, 15 \mathrm{~V}$, and $60 \mathrm{~min}$, providing a high SCGE sensitivity and definition of the comet image. The improved method is useful for detecting cryopreserved sperm DNA damage of some marine teleosts, especially for testing the quality of genetic resources.
\end{abstract}

KEY WORDS: Pseudosciaena crocea · Sperm · Cryopreservation · SCGE · DNA damage

\section{INTRODUCTION}

Single-cell gel electrophoresis (SCGE), or the comet assay, is a classical method for the detection of DNA damage (Singh et al. 1988, Rojas et al. 1999). This assay follows the process of cell lysis and DNA unwinding; the DNA fragments flow from the nucleus and move to the positive pole, generating a comet-like band. After fluorescent staining, DNA damage of the cells can be observed under the microscope. The fluorescence intensity of the comet tail depends on the degree of DNA damage. SCGE is widely used for detection of DNA damage in plant cells (Kim \& Richard 2004), mice cells (Giovannelli et al. 2003), lymphocytes (Stavreva et al. 1998), human sperm (Lu et al. 2002), and fish sperm (Labbe et al. 2001, Xu et al. 2005, Ye et al. 2009). Although SCGE alkaline comet assay can detect DNA damage fast and with high sensitivity, it does not work well for cryopreserved sperm of marine teleosts. In order to obtain higher sensitivity, we improve the classic SCGE method by using large yellow croaker Pseudosciaena crocea sperm cryopreserved in increasing concentrations (5 to $30 \%$ ) of DMSO.

\section{MATERIALS AND METHODS}

Samples and materials. Male yellow croakers Pseudosciaena crocea of 500 to $650 \mathrm{~g}$ were obtained from Haiwang Hatchery, Xiangshan, Zhejiang Province, China, in March 2008.

Low melting-point agarose (LMA), EDTA, sodium sarcosinate, Triton X-100, proteinase K, Tris, DMSO and ethidium bromide (EB) staining solution were purchased from Shanghai Santa Bio-Techonology. All reagents were analytically pure grade. A DYY2C 
electrophoresis apparatus and a DYCP-33A electrophoresis bath were purchased from Liuyi Instrument Company. A Nikon ECLIPSE 80i fluorescence microscope was purchased from Nikon Corporation; and CometScore 1.5 image analysis software was from TriTek Corporation.

Sperm cryopreservation. Fresh semen was collected from 5 anesthetized male fish. Semen was mixed with the extender, which contained Cortland solution and 5 to $30 \%$ DMSO with a volume proportion of 1:3. The suspension was put on ice for 10 to $15 \mathrm{~min}$ and then injected into $500 \mu \mathrm{l}$ straws. The straws were then placed horizontally 3 to $5 \mathrm{~cm}$ above the liquid nitrogen surface. After 5 to 8 min freezing, the straws were plugged into nitrogen for storage. Each DMSO concentration treatment was repeated 4 times.

SCGE procedure. Straws were thawed in a water bath at $40^{\circ} \mathrm{C}$, centrifuged $(344 \times g)$ and washed twice with phosphate buffered saline (PBS; pH 7.4) at $4^{\circ} \mathrm{C}$. The sperm suspension $(50 \mu \mathrm{l}$, with concentration of approximately $8 \times 10^{6}$ sperm $\mathrm{ml}^{-1}$ ) was diluted with $350 \mu \mathrm{l} 1 \%$ LMA in a $5 \mathrm{ml}$ centrifuge tube; the final sperm concentration was $10^{6}$ sperm $\mathrm{ml}^{-1}$. The sperm suspension was then placed in a lysis solution $(2.5 \mathrm{M}$ $\mathrm{NaCl}, 100 \mathrm{mM}$ EDTA, $10 \mathrm{~g} \mathrm{l}^{-1}$ sodium sarcosinate, $10 \%$ DMSO, $1 \%$ Triton X-100, pH10) for $1 \mathrm{~h}$ at $10^{\circ} \mathrm{C}$. This step and the following steps (except staining and observation) were performed in the dark. The sperm suspension was placed in a digestive solution (2.5 M NaCl, $5 \mathrm{mM}$ Tris, $0.5 \mathrm{~g} \mathrm{l}^{-1}$ sodium sarcosinate, $0.5 \mathrm{~g} \mathrm{l}^{-1}$ proteinase $\mathrm{K}, \mathrm{pH} \mathrm{7.4)}$ in a water bath at $55^{\circ} \mathrm{C}$ for $3 \mathrm{~h}$. After washing with PBS twice, the mixture was melted at $70^{\circ} \mathrm{C}$ in a water bath for $3 \mathrm{~min}$, then a $100 \mu \mathrm{l}$ drop of the mixture was pipetted on the slide, covered with a coverslip and allowed to solidify at $10^{\circ} \mathrm{C}$ for $10 \mathrm{~min}$. The slides were placed in a horizontal electrophoresis bath with a fresh alkaline electrophoresis solution (300 mM sodium acetate, $100 \mathrm{mM}$
Tris, pH 10.0) for 30 min to allow the DNA to unwind. Electrophoresis was carried out using a current of $130 \mathrm{~mA}$ and $15 \mathrm{~V}$ for $1 \mathrm{~h}$. The slides were then neutralized in a freshly prepared Tris- $\mathrm{HCl}$ buffer (0.4 mM, pH 7.0) for 15 min.

The slides were stained with EB solution (50 $\mu \mathrm{g}$ $\mathrm{ml}^{-1}$ ) for $10 \mathrm{~min}$, and then photographed on an epifluorescence microscope with an excitation wavelength of $580 \mathrm{~nm}$. Each sample was measured 4 times, and 100 sperm from each slide were observed.

Image analysis. The comet image was analyzed with CometScore 1.5 software (Ye et al. 2009) to obtain parameters such as comet length, tail length, and DNA percentage in the tail.

Comet rate and damage coefficient calculation. According to the method of Singh et al. (1988) and Rojas et al. (1999), DNA damage was divided into 5 grades, depending on tail length as a proportion of total length.

Grade 0: no damage, normal cell, tail length $<5 \%$, nucleus was intact (Fig. 1a).

Grade I: slightly damaged, tail length 5 to $20 \%$ (Fig. 1b).

Grade II: moderately damaged, tail length 20 to $40 \%$, obvious tail observed (Fig. 1c).

Grade III: heavily damaged, tail length 40 to $95 \%$, fluorescence signal becomes strong, nucleus reduced significantly (Fig. 1d).

Grade IV: totally damaged, tail length >95\%, nucleus becomes dim or disappears altogether, fluorescence signal becomes extremely strong (Fig. 1e).

Comet rate and damage coefficient were calculated as follows:

Comet rate $=($ comet cells $/$ total cells $) \times 100$;

Damage coefficient $=[($ Grade 0 cell number $\times 0)+$ $($ Grade I cell number $\times 1)+($ Grade II cell number $\times 2)$ $+($ Grade III cell number $\times 3)+($ Grade IV cell number $\times 4)$ ] (Chen 1998).
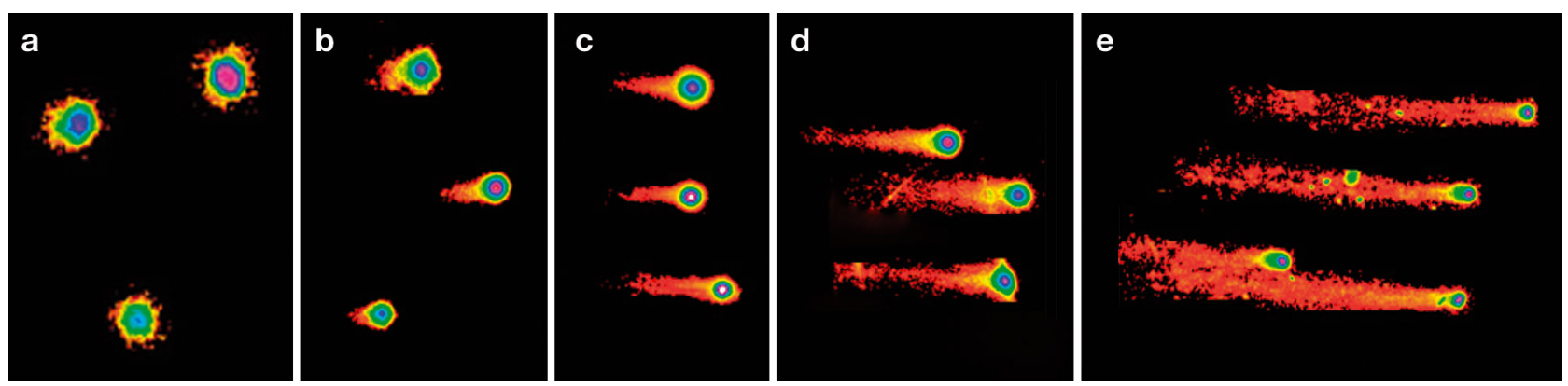

Fig. 1. Single-cell alkaline comet assay gel electrophoresis of fresh and cryopreserved sperm. (a) Grade 0, normal cell; (b) Grade I, slightly damaged, comet tail short; (c) Grade II, weakly damaged, nucleus reduced, fluorescence signal of tail stronger; (d) Grade III, strongly damaged, nucleus reduced significantly, strong fluorescence signal of tail; (e) Grade IV, totally damaged, very long comet tail. Magnification: ca. 2000x 


\section{RESULTS AND DISCUSSION}

In fresh and cryopreserved sperm, comet and tail length showed an increasing correlation with concentration of the cryoprotectant DMSO (Fig. 1). We set 6 different DMSO dilutions, which were marked as D1-D6, with concentrations increasing from 5 to $30 \%$ DMSO in $5 \%$ increments. Compared with fresh sperm, comet length and tail length of D1-D4 were similar to that of fresh sperm (Fig. $1 \mathrm{a}-\mathrm{C}$ ), but the comet length and tail length of D5 and D6 were obviously longer than that of fresh sperm (Fig. 1d,e). A detailed analysis is in preparation

Since the alkaline comet assay was reported by Singh et al. (1988), continuous improvement has made it feasible to detect not only double-strand breaks but also single-strand breaks at alkaline fragile sites quickly and with high sensitivity (Yang et al. 2004). We made some modifications to the classic SCGE method used in our previous investigations on Sparus macrocephalus (Ye et al. 2009). The improvements include: (1) common microscopic slides without rough (frosted) surfaces were used because common slides have a better light transmittance and definition and lower price than manufactured SCGE slides; (2) pretreatment of sperm was carried out before gel spread, which simplified the procedure of SCGE and reduced the degelatinization and dosage of Protease K rapidly; (3) in contrast to 2 or 3 layers of gel, the spread of a single layer of gel turned out to be more convenient, with less degelatinization occurring; (4) electrophoresis conditions are different between sperm from different species, and for the yellow croaker sperm, $130 \mathrm{~mA}, 15 \mathrm{~V}$, and $60 \mathrm{~min}$ provided a high SCGE sensitivity and definition of the comet image (Ye et al. 2009).

In our SCGE analysis, we employed both manual index analysis and computer image analysis. Manual index analysis refers to the measurement of comet rate and distance index (head length, tail length, etc.), which are easy to measure but provide relatively rough estimates.
Acknowledgements. This study was supported in part by the following projects: National Natural Science Foundation of China (no. 41276151), Research Foundation of Ningbo University (grant no. XK0715043), Projects of Department of Sci-Technology of Ningbo City (2006C100044, 2007A31004 to J.Q.Z.), and National Natural Science Foundation of China (grant nos. 40776079 and 30671606 to W.X.Y.).

\section{LITERATURE CITED}

Chen A (1998) Detection of DNA damage on single cell using single cell gel electrophoresis. Foreign Med Sci 19: 145-146 (in Chinese)

Giovannelli L, Decorosi F, Dolara P, Pulvirenti L (2003) Vulnerability to DNA damage in the aging rat substantia nigra: a study with the comet assay. Brain Res 969: 244-247

Kim GB, Richard FL (2004) Effects of genotoxic compounds on DNA and development of early and late grass shrimp embryo stages. Mar Environ Res 57:329-338

Labbe C, Martoriati A, Devaux A, Maisse G (2001) Effect of sperm cryopreservation on sperm DNA stability and progeny development in rainbow trout. Mol Reprod Dev 60:397-404

Lu HO, Zhang L, Zhang N, Tang J, Ding XP, Tang Y (2002) Detection of DNA damage of human sperm using single cell electrophoresis. Zhonghua Nan Ke Xue 8:416-418 (in Chinese)

Rojas E, Lopez MC, Valverde M (1999) Single cell gel electrophoresis assay: methodology and applications. J Chromatogr B Biomed Sci Appl 722:225-254

Singh NP, McCoy MT, Tice RR, Schneider EL (1988) A simple technique for quantitation of low levels of DNA damage in individual cells. Exp Cell Res 175:184-191

Stavreva DA, Ptáček O, Plewa MJ, Gichner T (1998) Single cell gel electrophoresis analysis of genomic damage induced by ethyl methanesulfonate in cultured tobacco cells. Mutat Res 422:323-330

Xu XC, Ding FH, Li J (2005) Cryopreservation caused sperm DNA damage in red sea bream Pagrosomus major and its detection. Oceanol Limnol Sin 36:221-225 (in Chinese)

Yang JY, Li L, Peng Y, Du SJ (2004) DNA damage caused by low dose methotrexate and protective effect of folinic acid. Carcinog Teratog Mutagen 16:24-26

> Ye T, Zhu JQ, Yang WX, Wei P, Wu XF (2009) Sperm cryopreservation in Sparus macrocephalus and DNA damage detection with SCGE. Zool Res 30:151-157 (in Chinese)

Submitted: September 28, 2012; Accepted: February 11, 2013 Proofs received from author(s): March 7, 2013 